Full length article

\title{
Valuable but vulnerable: Over-fishing and under-management continue to threaten groupers so what now?
}

Yvonne J. Sadovy de Mitcheson ${ }^{\mathrm{a}, \mathrm{b}}$, Christi Linardich ${ }^{\mathrm{c}}$, João Pedro Barreiros ${ }^{\mathrm{d}}$, Gina M. Ralph ${ }^{\mathrm{c}}$, Alfonso Aguilar-Perera ${ }^{e}$, Pedro Afonso ${ }^{\text {f,g,h }}$, Brad E. Erisman ${ }^{i}$, David A. Pollard ${ }^{j}$, Sean T. Fennessy ${ }^{k}$, Athila A. Bertoncini ${ }^{1, m}$, Rekha J. Nair ${ }^{\mathrm{n}}$, Kevin L. Rhodes ${ }^{\mathrm{o}}$, Patrice Francour $^{\mathrm{p}}$, Thierry Brulé ${ }^{\mathrm{q}}$, Melita A. Samoilys ${ }^{\mathrm{r}}$, Beatrice P. Ferreira ${ }^{\mathrm{s}}$, Matthew T. Craig ${ }^{\mathrm{t}, *}$

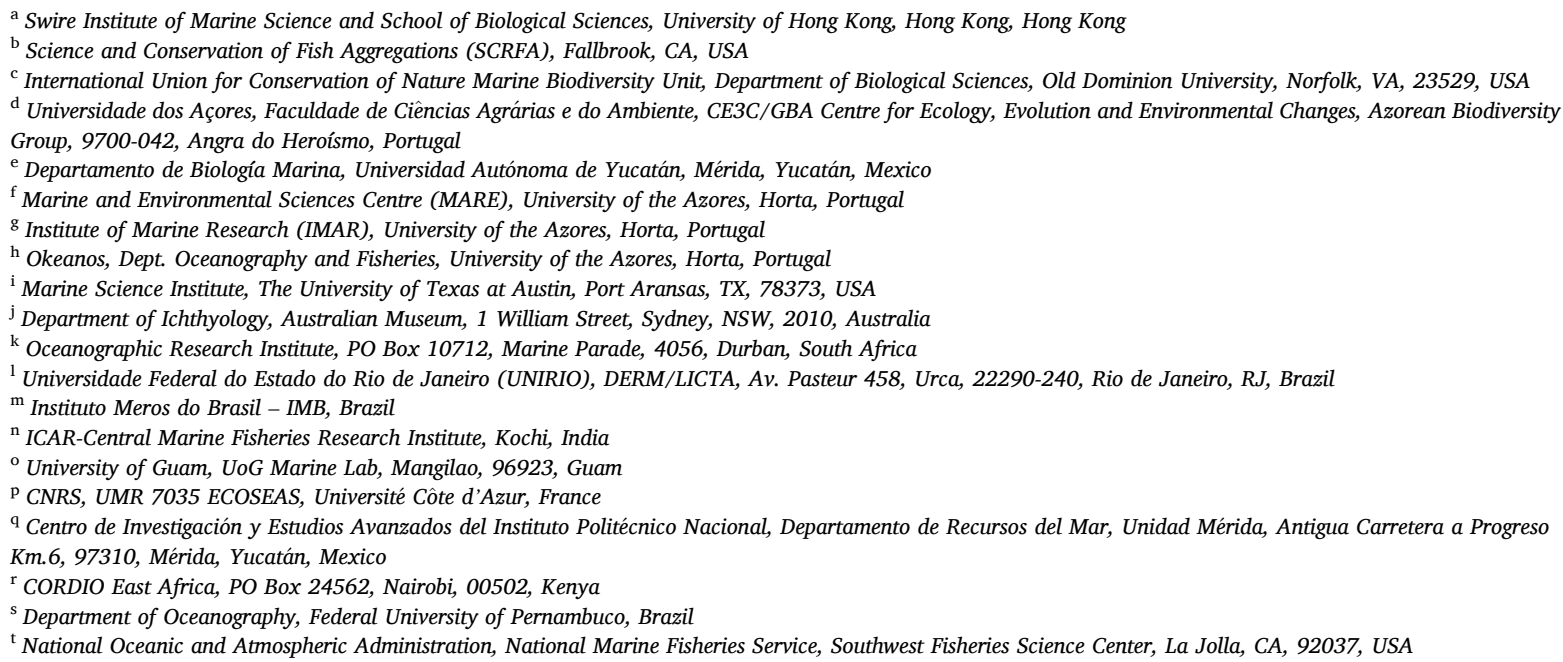

\section{A R T I C L E I N F O}

During the review of this paper, our co-author, colleague, and friend, Patrice Francour, passed away at the age of 59 . We dedicate this paper to Patrice's memory in recognition of his commitment to the conservation of the Mediterranean Sea and its resources.

\section{Keywords:}

Epinephelidae

Extinction risk

\begin{abstract}
A B S T R A C T
Among threats to marine species, overfishing has often been highlighted as a major contributor to population declines and yet fishing effort has increased globally over the past decade. This paper discusses the decadal reassessment of groupers (family Epinephelidae), an important and valuable group of marine fishes subjected to high market demand and intense fishing effort, based on IUCN criteria. Allowing for uncertainty in the status of species listed as Data Deficient, 19 species (11.4\%) are currently assigned to a "threatened" category. This first reassessment for a large marine fish taxon permits an evaluation of changes following the original assessments, provides a profile of the current conservation condition of species, identifies the challenges of assessing conservation status, and highlights current and emerging threats. Measures needed to reduce threats and lessons learned from conservation efforts are highlighted. Present threats include intensifying fishing effort in the face of absent or insufficient fishery management or monitoring, growing pressures from international trade, and an
\end{abstract}

\footnotetext{
* Corresponding author. beatricepadovaniferreira@gmail.com (B.P. Ferreira), matthew.craig@noaa.gov (M.T. Craig).

E-mail addresses: yjsadovy@hku.hk (Y.J. Sadovy de Mitcheson), clina001@odu.edu (C. Linardich), joao.ps.barreiros@uac.pt (J.P. Barreiros), gralph@odu.edu (G.M. Ralph), alfaguilar@gmail.com (A. Aguilar-Perera), pafonsopim@gmail.com (P. Afonso), berisman@utexas.edu (B.E. Erisman), dave-pollard@bigpond.com (D.A. Pollard), seanf@ori.org.za (S.T. Fennessy), athilapeixe@gmail.com (A.A. Bertoncini), rekhacmfri@gmail.com (R.J. Nair), klrhodes_grouper@yahoo.com (K.L. Rhodes), Patrice.francour@univ-cotedeazur.fr (P. Francour), tbrule@cinvestav.mx (T. Brulé), melita.samoilys@gmail.com (M.A. Samoilys), 
IUCN

Overfishing

Sustainability inadequate coverage in effectively managed, sized, or located protected areas. Emerging threats involve expansion of fishing effort into deeper waters and more remote locations, shifts to previously non-targeted species, increases in the capture, marketing and use of juveniles, growing demands for domestic and international trade, and, potentially, climate change. Those species most threatened are larger-bodied, longer-lived groupers, most of which reproduce in spawning aggregations.

\section{Introduction}

Global fishing effort is increasing and the implications of this increase are ever more apparent across the world's oceans (e.g. Ref. [1]). Compounded by the effects of climate forcing and habitat degradation, overfished marine fish populations continue to dwindle. In many areas, this pattern is unchecked due to the difficulties of enforcing regulations, and, in many cases, lax or absent management of fisheries or trade. It is therefore important to identify the major sources of risk to marine populations, to be vigilant in monitoring the response of populations to these impacts, and to seek ways to mitigate them.

Established in 1964, the International Union for Conservation of Nature's (IUCN) Red List of Threatened Species (RL) has emerged as one of the most widely recognized and comprehensive sources for information on the conservation status of animal, fungi, and plant species. The IUCN RL is used by a variety of organizations including government agencies, wildlife and fisheries departments, non-governmental organizations (NGOs), and many other groups. The IUCN Species Survival Commission (SSC) comprises numerous specialist groups that are defined by taxonomic (e.g., Salmon) or functional (e.g., Sustainable Use) groups. Each specialist group is responsible for assessing species in terms of threats and extinction risk following the IUCN RL criteria. Ideally, species are reassessed at least every ten years to ensure up-to-date classifications, sooner if they are at a particularly high-risk level. The enormous economic value of grouper fisheries and their importance for livelihoods and food security in the tropics and subtropics, as well as acknowledgement of the important role of groupers in reef ecosystems, prompted the completion of all grouper assessments by the Groupers and Wrasses Specialist Group (GWSG) in 2007 [2]. The current paper describes and discusses the decadal reassessment of this important group of marine fishes that was undertaken in November 2016.

\section{Methods}

\subsection{Taxonomic scope}

The global assessments reported on herein include 167 grouper species which represents all valid species at the time of the reassessment workshop in 2016. Smith and Craig [3] demonstrated the non-monophyly of the traditional family "Serranidae" which has been confirmed by all molecular phylogenies with adequate taxon sampling, a necessity for this group as highlighted by Smith and Craig ([3], e.g., Refs. [4,5]). Smith and Craig [3] elevated the subfamily "Epinephelinae" (sensu $[6,7]$ ) to familial status. With the exception of the tribe Niphonini (the genus Niphon having been confirmed to be unrelated to the traditional "Serranidae" (e.g., Ref. [3,8], the tribes within Johnson's [6,7]) "Epinephelinae" (Diploprionini, Epinephelini, Grammistini, and Liopropomini) are now treated as subfamilies within Epinephelidae (sensu $[3,9]$ ). Thus, the true groupers (species in the genera Aethaloperca, Alphestes, Anyperodon, Cephalopholis, Cromileptes, Dermatolepis, Epinephelus, Gonioplectrus, Gracila, Hyporthodus, Mycteroperca, Paranthias, Plectropomus, Saloptia, Triso, and Variola) are here treated as members of the subfamily Epinephelinae within the family Epinephelidae. Ma and Craig [9] provided an updated taxonomy for the grouper genera (largely following Craig and Hastings [10]), that altered the generic placement of many species. These taxonomic changes have not yet all been incorporated into the IUCN database and the usage of traditional generic names in the current assessments simply reflects that the database has yet to be updated.

\subsection{IUCN Red List methodology}

The IUCN Red List is based on two paradigms of extinction risk: species with small and/or decreasing populations are at a higher risk of extinction than those with large and/or stable populations [11]. These two patterns in extinction risk are the foundation of the five RL criteria: A- population decline in the past, present and/or future; B- small geographic range; C- small population size and decline; D- very small or restricted population; and E- quantitative analysis (IUCN, 2012). Species are listed in one of the three "threatened" categories (Critically Endangered [CR], Endangered [EN], and Vulnerable [VU]) if they meet the quantitative thresholds and conditions of any one of the above five criteria; species that nearly meet the thresholds and conditions are listed as Near Threatened (NT). Least Concern (LC) species are those that do not approach the thresholds and conditions for a "threatened" category (e.g., they may have a very large range, a large and/or stable population, and/or a lower rate of population decline, etc.). When the available information is not sufficient to confidently place a species in one or another of the above categories it is listed as Data Deficient (DD); this may be due to a lack of information or because the limited information that is available could result in a wide range of potential categories. A species is listed as Extinct (EX) or Extinct in the Wild (EW) if there is no reasonable doubt that the last individual, or the last wild individual, has died. None of the groupers were listed as EX or EW.

To use criterion A, two estimates are needed: generation length and population decline over three generation lengths, which may include the past, present, and/or future, and can be assessed using a proxy for population abundance (such as catch per unit of effort in the case of exploited species). The generation length is a measure of the turnover rate in the population, and thus scales population declines to a time window that is meaningful for the species under consideration. For these reassessments, generation time (GT) was calculated following Depczynski and Bellwood [12] as: $\mathrm{GT}=\mathrm{AM}+\left(\mathrm{T}_{\max }-\mathrm{AM}\right) / 2$, where $\mathrm{AM}=$ age at female maturity and $\mathrm{T}_{\max }=$ maximum known age (with ages in years).

To meet the thresholds for a threatened species listing under criterion $\mathrm{B}$, the Area of Occupancy (AOO) and Extent of Occurrence (EOO) must be estimated and a major threat must be identified. Only one species, Mycteroperca fusca, the Island grouper, was assessed under criterion $\mathrm{B}$, in part due to most groupers having distributions that greatly exceed the AOO and EOO thresholds. None of the groupers were assessed as threatened under criteria C, D, or E.

All valid grouper species were initially assessed between 2003 and 2011 (see Refs. [2]). However, an important component of the Red List is the mandate to complete reassessments at least every 10 years to track changes in the status of species through time. As a result, 24 members of the IUCN Groupers and Wrasses Specialist Group (GWSG) assembled for a reassessment workshop at the University of the Azores in November 2016. Following completion of the RL review process, the assessments were published on the IUCN RL website in November 2018.

When all of the species in a given taxon are assessed, there may be uncertainty in the actual number of species in a "threatened" category due to the presence of species in the DD category. Because of this uncertainty, an estimate for the proportion of threatened species is often calculated as the midpoint, assuming that the DD species are as threatened as the species for which data were sufficient to assess (i.e., (CR + 
$\mathrm{EN}+\mathrm{VU}) /($ all-DD)). However, as there is uncertainty surrounding the true status of the DD species, a lower (i.e., $(\mathrm{CR}+\mathrm{EN}+\mathrm{VU}) /($ all) $)$ and upper (i.e., (CR + EN + VU + DD)/(all)) bound provide endpoints for a plausible range $[13,14]$.

\subsection{Species distributions and spatial analyses}

The generalized distribution maps created following the first global assessment (e.g., Ref. [2]) in ArcMAP 10.4 were modified to incorporate new data and maps were created for four previously undescribed species. All known or inferred localities where the species are found were included based on museum, photographic, and fish market records, and verified by taxonomic experts. One species, Epinephelus lebretonianus, the Mystery grouper, is known from a single specimen collected somewhere in the Indo-West Pacific, but for which no specific locality information is available; therefore, a map was not created for this species. Species richness analyses (all species, species of elevated conservation concern, and Data Deficient species) were completed by converting the generalized distribution polygon for each species to a $10 \mathrm{~km}$ by $10 \mathrm{~km}$ raster and summing the number of species in each raster cell.

\section{Results}

\subsection{Status of groupers}

Nineteen grouper species (11.4\%) were placed in a "threatened" category. Based on these assessments, the best estimate for the actual proportion of threatened species is $13.4 \%$, with a range of $11.4 \%$ (assuming none of the DD species are threatened) to $26.3 \%$ (assuming all of the DD species are threatened; see methods). Those species within the "threatened" categories were more likely to be large $(>50 \mathrm{~cm}$ total length) (Fig. 1), long-lived ( $>20$ years), and contain a disproportionate number of groupers known to aggregate to spawn (13 out of 14 threatened species of known reproductive mode).

\subsection{Changes to Red List categories}

Table 1 shows the previous and current Red List categories for all species that changed category in the reassessment process. Overall, 71 of 167 (42.5\%) species had a change of category from the previous assessments. Notably, more than half of these changes (36) involved species previously assessed as DD. In all but one instance, the species

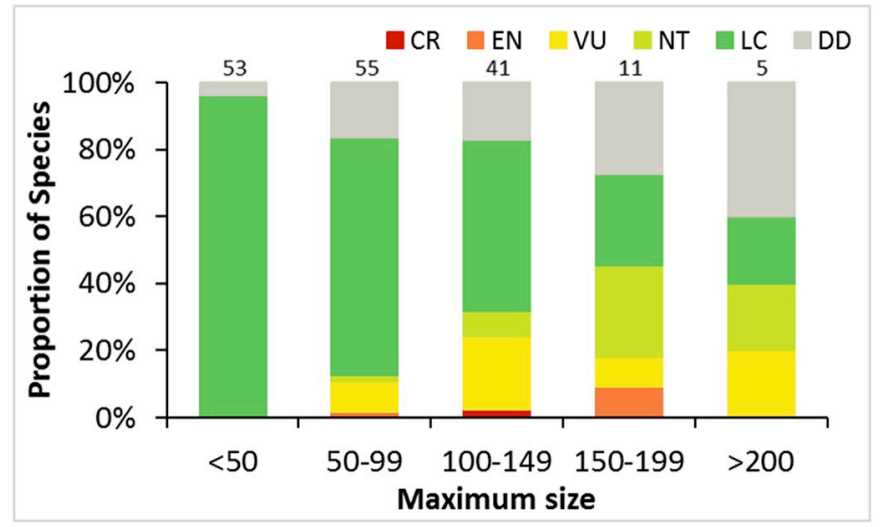

Fig. 1. Proportion of species in each of the Red List categories (CR: Critically Endangered; EN: Endangered; VU: Vulnerable; NT: Near Threatened; LC: Least Concern; DD: Data Deficient) as a function of maximum reported size (total length) $\mathrm{N}=165$; maximum size was not reported for two species listed as Data Deficient (Epinephelus lebretonianus and E. suborbitalis, which are known only from unique holotypes). $\mathrm{X}$-axis is maximum size (total length) in $\mathrm{cm}$. (For interpretation of the references to colour in this figure legend, the reader is referred to the Web version of this article.)
Table 1

List of groupers for which the current Red List status differed from its original status. DD = Data Deficient; LC = Least Concern; NT = Near Threatened; VU = Vulnerable; EN = Endangered; $\mathrm{CR}=$ Critically Endangered.

\begin{tabular}{|c|c|c|}
\hline Species name & Current Status & Previous Status \\
\hline Aethaloperca rogaa & LC & DD \\
\hline Cephalopholis aitha & LC & DD \\
\hline Cephalopholis aurantia & LC & DD \\
\hline Cephalopholis hemistiktos & LC & NT \\
\hline Cephalopholis igarashiensis & LC & DD \\
\hline Cephalopholis nigripinnis & LC & DD \\
\hline Cephalopholis taeniops & LC & DD \\
\hline Cromileptes altivelis & DD & VU \\
\hline Dermatolepis inermis & DD & NT \\
\hline Dermatolepis striolata & LC & DD \\
\hline Epinephelus amblycephalus & LC & $\mathrm{DD}$ \\
\hline Epinephelus bilobatus & LC & DD \\
\hline Epinephelus bleekeri & DD & NT \\
\hline Epinephelus bontoides & LC & $\mathrm{DD}$ \\
\hline Epinephelus chabaudi & LC & $\mathrm{DD}$ \\
\hline Epinephelus cifuentesi & LC & NT \\
\hline Epinephelus coioides & LC & NT \\
\hline Epinephelus corallicola & LC & DD \\
\hline Epinephelus diacanthus & LC & NT \\
\hline Epinephelus drummondhayi & $\mathrm{DD}$ & $\mathrm{CR}$ \\
\hline Epinephelus epistictus & LC & DD \\
\hline Epinephelus erythrurus & LC & $\mathrm{DD}$ \\
\hline Epinephelus fasciatomaculosus & LC & DD \\
\hline Epinephelus faveatus & LC & DD \\
\hline Epinephelus fuscoguttatus & $\mathrm{VU}$ & NT \\
\hline Epinephelus gabriellae & LC & VU \\
\hline Epinephelus goreensis & NT & DD \\
\hline Epinephelus heniochus & LC & DD \\
\hline Epinephelus itajara & VU & $\mathrm{CR}$ \\
\hline Epinephelus lanceolatus & DD & VU \\
\hline Epinephelus latifasciatus & LC & DD \\
\hline Epinephelus magniscuttis & LC & $\mathrm{DD}$ \\
\hline Epinephelus malabaricus & LC & NT \\
\hline Epinephelus marginatus & $\mathrm{VU}$ & EN \\
\hline Epinephelus melanostigma & LC & DD \\
\hline Epinephelus morio & $\mathrm{VU}$ & NT \\
\hline Epinephelus polylepis & LC & NT \\
\hline Epinephelus polyphekadion & $\mathrm{VU}$ & NT \\
\hline Epinephelus polystigma & LC & DD \\
\hline Epinephelus retouti & LC & DD \\
\hline Epinephelus sexfasciatus & LC & DD \\
\hline Epinephelus socialis & LC & NT \\
\hline Epinephelus stoliczkae & LC & DD \\
\hline Epinephelus striatus & $\mathrm{CR}$ & EN \\
\hline Epinephelus summana & LC & DD \\
\hline Epinephelus timorensis & LC & DD \\
\hline Epinephelus undulatostriatus & LC & $\mathrm{DD}$ \\
\hline Epinephelus undulosus & LC & $\mathrm{DD}$ \\
\hline Gracila albomarginata & LC & DD \\
\hline Hyporthodus acanthistius & VU & LC \\
\hline Hyporthodus ergastularius & NT & LC \\
\hline Hyporthodus exsul & LC & DD \\
\hline Hyporthodus haifensis & LC & $\mathrm{DD}$ \\
\hline Hyporthodus nigritus & NT & CR \\
\hline Hyporthodus niphobles & LC & DD \\
\hline Hyporthodus octofasciatus & LC & DD \\
\hline Hyporthodus quernus & LC & NT \\
\hline Hyporthodus septemfasciatus & DD & LC \\
\hline Mycteroperca fusca & VU & EN \\
\hline Mycteroperca microlepis & $\mathrm{VU}$ & LC \\
\hline Mycteroperca phenax & DD & LC \\
\hline Mycteroperca prionura & DD & NT \\
\hline Mycteroperca rosacea & LC & VU \\
\hline Mycteroperca tigris & $\mathrm{DD}$ & LC \\
\hline Mycteroperca xenarcha & DD & LC \\
\hline Plectropomus laevis & LC & VU \\
\hline Plectropomus leopardus & LC & NT \\
\hline Plectropomus oligacanthus & LC & NT \\
\hline Plectropomus pessuliferus & LC & NT \\
\hline Plectropomus punctatus & LC & DD \\
\hline Saloptia powelli & LC & $\mathrm{DD}$ \\
\hline
\end{tabular}


previously assessed as DD were reassessed as LC, the exception being Epinephelus goreensis (Dungat grouper) which moved from DD to NT. Seven species previously assessed as LC were reassessed as DD (4), VU (2), and NT (1). Seventeen species previously assessed as NT were reassessed as DD (3), LC (11), and VU (3). Five species previously assessed as VU were reassessed as LC (3) and DD (2). Three species previously assessed as EN were reassessed as VU (2) and CR (1). Three species previously assessed as CR were reassessed as DD, NT, and VU. In addition, 14 species retained the same NT or threatened category as the previous assessment, but all except Epinephelus akaara (Hong Kong grouper) had changes to the subcriteria in the reassessment. All of these changes in status, except that for Hyporthodus ergastularius (Sevenbar grouper), were considered non-genuine changes (see discussion below).

\subsection{Species richness}

Species richness in groupers is highest in the Indo-West Pacific, with upwards of 50 species per $100 \mathrm{~km}^{2}$ in Taiwan, the Philippines, western Indonesia and Papua New Guinea. Despite relatively fewer grouper species in the Western Atlantic (less than 20 species per $100 \mathrm{~km}^{2}$ ), the region is home to the highest numbers of species of elevated conservation concern (CR, EN, VU and NT) with 8-10 threatened species per 100 $\mathrm{km}^{2}$ (Fig. 2a and b). The highest richness of species listed as Data
Deficient occurs in East Asia, around China, Taiwan and Hong Kong, with 5-7 species per $100 \mathrm{~km}^{2}$ (Fig. 2c).

Although most threatened species occur in the Western Atlantic, most DD species are in the area of highest species diversity where there is heaviest fishing pressure and minimal management, east and SE Asia. Hence, it is likely that some of the DD species may also be threatened or will become so if management is not forthcoming. Asia is also the region where fishing intensity for groupers is growing and the most intense but also where there are relatively few workers focusing on groupers or programs for monitoring of catches and landings.

\section{Discussion}

\subsection{Changes to Red List categories}

This update of the grouper RL assessments represents the first large group of marine fishes to be completely reassessed. Among all previously assessed groupers, nearly half (42.5\%) were determined to belong to a different RL category from the previous assessment. This large proportion of species that changed categories highlights the importance of the reassessment process, especially for harvested species. Many factors influencing our understanding of population dynamics can change over the decadal time period required for such reassessments, as

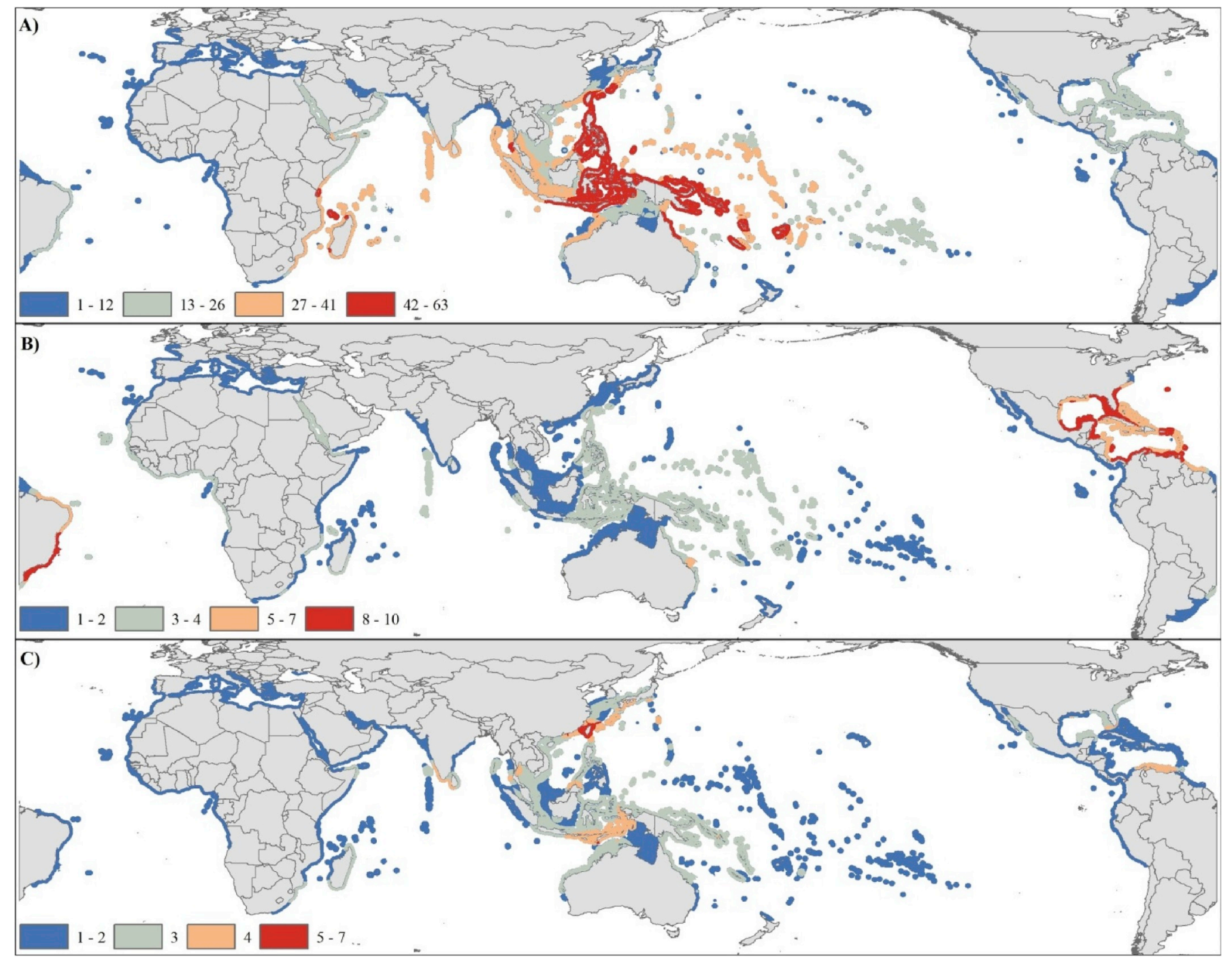

Fig. 2. Species richness of groupers per $100 \mathrm{~km}^{2}$ grid cell for A) all species $(\mathrm{n}=166)$; B) species of elevated conservation concern (i.e. threatened or NT) ( $\left.\mathrm{n}=27\right)$ and C) Data Deficient species $(\mathrm{n}=24)$. Note that Epinephelus lebretonianus was excluded from all analyses because the type locality is unknown. 
can fishing intensity and understanding of the impacts of fishing.

In the reassessment process, there are many possible reasons for a taxon to change categories. Harvest levels may change, populations may rebound or decline, biological and/or fishery data may improve, and the assessment process itself may become better defined. The RL process considers two types of changes to a species' status that depend on the type of information used to justify a change in category: genuine and non-genuine. A genuine change in category is determined by demonstrated increases or decreases in the level of extinction risk to a species. This is often reflected by increases or decreases in abundance. Nongenuine changes of category occur when a perceived extinction risk changes due to an increase in the understanding of a species. Nongenuine changes are influenced by factors such as improved data, an increased understanding of the life history of an organism, or a more refined application of the Red List criteria.

For the 167 reassessments, only one species, Hyporthodus ergastularius, underwent a genuine change in category (from LC to NT). In this case, fishing effort increased and expanded to cover most of its range since it was first assessed in 2008. As a result, the population is suspected to have undergone a global-level decline of nearly $30 \%$ within the past generation ( $\sim 23$ years) and, in the absence of any changes, is expected to continue to decline over the next two generations. This species, endemic to southeastern Australia, should be closely monitored by management and regulatory agencies, and further studies on its life history are needed.

The majority of non-genuine changes were driven by two main factors: new information regarding a species and/or a more conservative application of the Red List criteria. New information often included a better understanding of harvest levels, increased knowledge of a species geographic range, and, for some species, an improved understanding of its life history. Over the past decade, more attention has been paid to life history data collection in fishes, including exploited species, and groupers are no exception. Better estimates of the longevity and age at first reproduction for many groupers significantly improved estimates of generation length, which enabled assessors to apply Red List criterion A with increased confidence. Moreover, improvements in, or access to, national and global databases has increased the information available. This information ranges from national fisheries statistics in the Philippines and COREMAP project underwater survey data from Indonesia, to several long-term regional underwater census databases and specialized data sources (see species assessments) such as that on spawning aggregations (www.SCRFA.org) that are increasingly accessible online or have now been in place for multiple years.

Perhaps more importantly many changes in category or subcriteria were driven by a more rigorous application of the Red List criteria. In the initial assessments, for example, global population decline was often based primarily on expert opinion. The reassessment process, instead, first considered the explicit data available to support expert opinion, and if those data were insufficient to at least suspect an estimated global population decline, then the species may have been reassessed in a different RL category. For example, many previous assessments had comprehensive data on harvest levels from only a limited proportion of a wide geographic range. These data were previously extrapolated to the entire range of the species; however, in the reassessment process the information was deemed insufficient to justify a global-level population decline for species with large ranges.

In addition, adjustments made in approaching these reassessments were informed by the most recent guidelines for using the RL categories and criteria [15], which have been repeatedly updated and refined since the original GWSG RL initiative occurred, including the guidance related to harvested marine species [15].

Overall, changes in assigned RL categories for nearly half of the grouper species underscores the importance of the reassessment process. Not only is it likely that new information will become available during the ten-year hiatus between assessments, but it is also a chance to improve the assessment quality through better understanding, as well as refinement, of the Red List criteria, and to identify and fill data gaps. For example, one particular challenge is the phenomenon referred to as the "ski jump" effect (Fig. 3). This arises when an initial population reduction is followed by an extensive period of stabilization at depressed population levels. It is apparent that major reductions in some marine fish populations have occurred well beyond the three generation time frame on which the RL criterion A is based. In these cases, if the past population reduction is used as a criterion, the true status of a species may not be captured despite the criterion being applied correctly. While the "ski jump" effect may be a common phenomenon in many fisheries, it is nearly impossible to detect due to a lack of historical data. In the case of groupers, the best-known example is that of the Nassau grouper, Epinephelus striatus (see Red List assessment).

Since declines in the size of unfished populations to levels that yield Bmsy (about 50\% virgin biomass at maximum sustainable yield) are acceptable fishery targets, it has been proposed that declines according to IUCN criteria may be in conflict with IUCN Criterion A decline levels in the case of exploited species (see Refs. [16]). However, more recent studies demonstrate that the Red List criteria are in line with fisheries assessments of stock status and do not exaggerate extinction risk (e.g. $[17,18,76])$. On the other hand, large historic declines may be followed by low levels of stable population numbers or by increases in numbers if management is successfully in place. Understandably, an important question is whether the long-term historical declines or the more recent increases should take precedence in the assessment of threat in such taxa [15]. However, the point of criterion A is that long-term trends (within three generation lengths) may indicate an underlying cause whereas recent, short-term trends may be temporary. Guidelines on the use of Criterion A, in the context of the ski jump effect and severely depleted populations, have been issued [19].

\subsection{Current and emerging threats}

Overexploitation, in both small- and industrial-scale fisheries, overwhelmingly remains the major threat to all grouper species assessed in

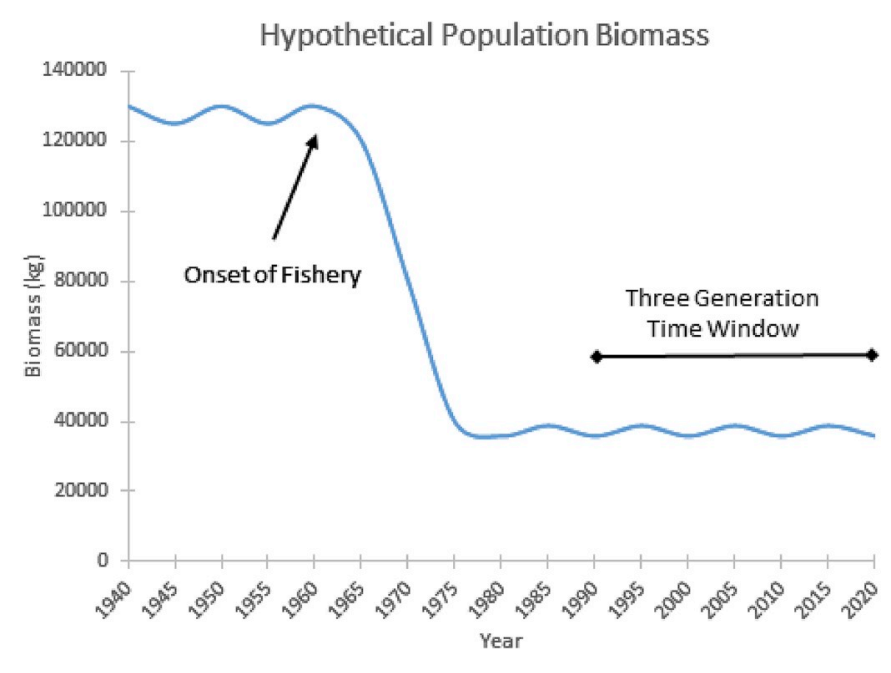

Fig. 3. Graphical representation of the "ski jump" effect. In this hypothetical scenario, the initiation of a new fishery in the 1960's was coincident with a rapid population decline until the mid-1970's when the population stabilized at a level of $\sim 30 \%$ of the unexploited population. Under criterion A, a $70 \%$ reduction in population would fall into the Endangered category, however, criterion A requires that the reduction be over a three generation time span. In this example, the three-generation time window does not include the observed population decline at the time of assessment, and thus the species could be categorized as Least Concern under criteria A1/A2 (past declines). The species would then need to be assessed against the other criteria, including A3 (projected future declines) and A4 (declines encompassing a time span that includes the past and future). 
NT or threatened RL categories globally. Other identified threats included coastal development and pollution. Compared to grouper assessments conducted a decade ago, there is now a more diverse range of species, sizes, and life history stages targeted in a growing number of countries for an expanding number of markets and over greater depth ranges in both small-scale and industrial fisheries [2]. Increasingly, smaller species and juveniles of larger species are being targeted, or taken as bycatch in multi-species or trawl fisheries or for grow-out to market size (in this last case production is likely to be recorded as aquaculture/mariculture rather than capture fisheries, thereby underrepresenting capture volumes) (e.g. Ref. [20-22] and see below). Species that have been untargeted are increasingly a focus of fishing (e.g. Cephalopholis sonnerati in the live fish trade to supplement supply of the similarly red, and highly sought-after, Plectropomus leopardus or smaller grouper species being sold chilled or frozen) [23].

What has improved little, if at all, over the last decade are monitoring, management, or trade controls in general or actions to address threats that arise from lack of controls or fishery oversight. With few exceptions, species identified as threatened a decade or more ago have not been better managed or conserved.

Growing demand from domestic and international markets and increasing prices reflect both the esteem with which groupers are held and their declining availability. While mariculture of a few species adds to production (although this practice includes the extensive wildcapture of juvenile fish for culture grow-out for certain species, including Plectropomus leopardus, Epinephelus coioides, and E. fuscoguttatus, among others, further adding fishing pressure on wild populations), demand for wild-caught fish continues to be high and fishing continues. At the global level, reported grouper landings from capture fisheries increased from about $237,000 \mathrm{mt}$ annually to almost 450,000 mt between 2006 (approximately the time of the first grouper assessments) and 2016 (Fig. 4) [24]. This is an almost doubling in landings reported over the last decade, most of which (about 85\%) are from south, southeast, and east Asia. At the national level, the highest grouper landings are reported from China $(128,000 \mathrm{mt})$ and Indonesia $(100,000 \mathrm{mt})$, together accounting for almost $60 \%$ of the landings reported to FAO. However, many countries do not report their grouper

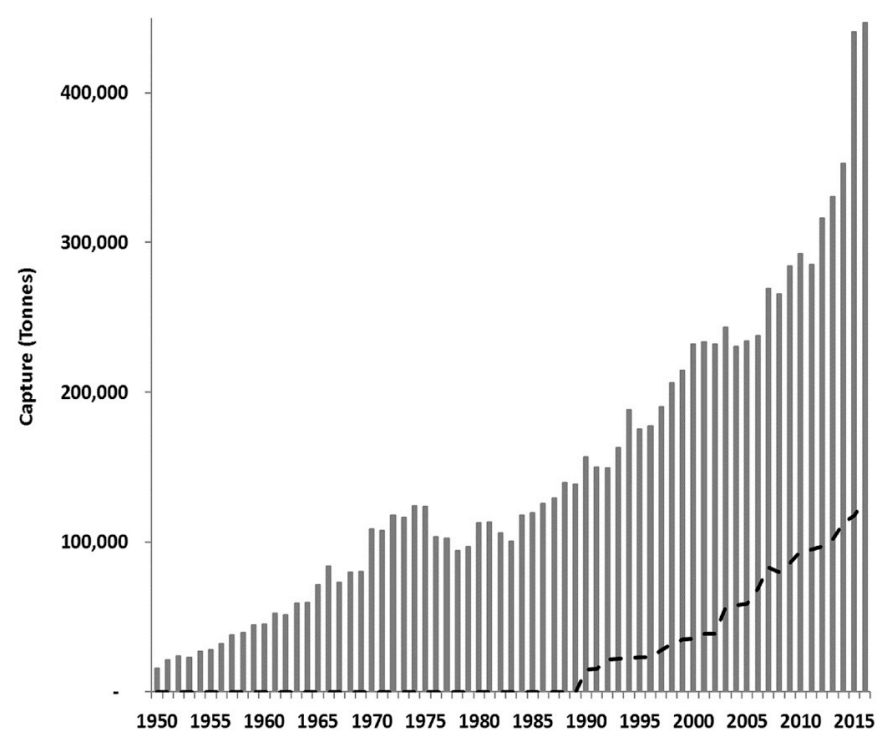

Year

Fig. 4. Grouper capture fisheries catches reported to FAO from 1950 to 2016 (grey bars) in tons. The dotted line shows the grouper catch data reported by China, represented separately according to current FAO practice These data are associated with some doubt because they were reported from the Northwest Pacific FAO fisheries region 61 which is not known to be a significant area for grouper production [24]. landings to FAO, while in the case of China the indicated grouper landings are almost certainly erroneous because they are reported to be from FAO fishing area 61 (Northwest Pacific), an area depauperate of groupers due to habitat/environmental conditions and/or prior depletion as in southern China. While it is possible that China's reported landings are from the country's distant water fleets and waters outside of China, landings from these fleets are not usually included in domestic landings databases. Hence the Chinese grouper data may seriously misrepresent catches of this taxon suggesting instead, relatively little absolute growth in grouper catches globally since the 1990s other than in the last few years (Fig. 4). In the Americas and in most other reporting countries outside of Asia, by contrast, reported landings are on the decline after peaking in the 1980s and 1990s [24].

The FAO data are minimum estimates due to considerable underreporting and poor reporting to species level (grouper species are often lumped into a general 'grouper' category in landings and trade data) typical of most small-scale fisheries (e.g. Ref. [25,26]) and to apparent mis-reporting, as in the case of China. As just one example, a major trade that is largely unreported to FAO (and not included in Fig. 4) is the international trade in live reef fish, mainly from southeast Asia into Hong Kong and Mainland China. To put the importance of this trade in context (in terms of volume), the current estimate of annual trade is at least 20,000 mt (accounting for inferred illegal, unregulated and unreported, or IUU, catches). This is roughly equivalent to the total annual landings now reported to FAO for the entire area of the Americas, and to $4-5 \%$ of total global reported landings of groupers in 2016, uncorrected for the over-reporting indicated above for China [23]. Nonetheless, overall and collectively the FAO data generally reflect the national level patterns indicated by other fishery and fishery-independent data included in the current grouper reassessments.

While overfishing is clearly the major threat, several threatened and NT species also face specific challenges associated with particular fisheries, aspects of their biology, or other factors such as climate change (see Red List assessments). For example, the VU Epinephelus fuscoguttatus (Brown-marbled grouper) and the VU Epinephelus polyphekadion (Camouflage grouper) are targeted as juveniles for the live fish trade because they are still juvenile at the restaurant-preferred 'plate-size', or because they are caught while still juvenile and grown to market-size due to growing scarcity of larger, market-sized, fish [23,27]. These and many other threatened species are also heavily targeted on their spawning aggregations. The NT and Threatened Epinephelus morio (Red grouper), E. marginatus (Dusky grouper), Hyporthodus acanthistius (Rooster hind), E. aeneus (White grouper), E. bruneus (Longtooth grouper) and H. nigritus (Warsaw grouper) are often taken as juveniles in bycatch [28]; JPB pers. comm.). The collapse of fisheries in the Gulf of California in the eastern Pacific affect at least two threatened groupers: $H$. acanthistius and M. jordani (Gulf grouper; [29-31]. For the CR Epinephelus striatus (Nassau grouper), spawning may be affected by climate change-related temperature shifts by reducing spawning probability for adult and reducing suitable habitat for non-spawners [32].

While most groupers have extensive geographic ranges and occupy a wide depth range, a few have limited distributions, while fishing pressure leaves few areas or species unexploited. Three groupers listed as VU, DD and NT that are endemic to a relatively small area extending from eastern South Africa to Mozambique (Epinephelus albomarginatus [White-edged grouper], E. posteli [Stripedfin grouper] and E. andersoni [Catface grouper]) are impacted by fishing pressure that is expanding and increasing throughout that area [33]. The expansion of fishing to deeper waters increases attention on the NT or threatened $H$. ergastularius, $H$. niveatus (Snowy grouper) and $H$. nigritus, and other deepwater species (e.g. Ref. [34]), and on the remaining refuges for shallow-water species. Escalating market prices lead to increasingly intensive sourcing for groupers across species, sizes and geographic distributions (see IUCN assessments). 


\subsubsection{So what now?}

Despite concerns about the conservation status of several grouper species for over a decade and negative implications for fisheries and income if declines continue, most regions where the majority of threatened groupers occur (e.g., the Gulf of Mexico/Caribbean, Gulf of Guinea, Mediterranean, Central and West Pacific, and SE Asia, see Fig. 2) have little or no management in place. With no improvement in management, and considering growing consumer demand, more species are likely to be threatened, resulting in further losses of benefits to humans from coastal ecosystems. Collectively such losses erode this important functional predatory group from reef ecosystems (e.g. Ref. [35]). Losing species (particularly large individuals) can also compromise the ecotourism value of groupers. For example, E. striatus, once the most important grouper in the insular Caribbean, was estimated to be worth far more alive than exploited in its spawning aggregations, both because of the tourism value of a spawning aggregation and for the reproductive value from the young produced in aggregations [36]. The VU Epinephelus itajara (Atlantic Goliath grouper) is much appreciated by recreational divers [37] and is the focus of many commercial dive operations where they are abundant.

Currently, only one species, E. striatus, is assessed as CR, the highest level of extinction risk established by IUCN. Despite a growing suite of management measures for this species over many decades in several countries, declines in abundance have continued. Factors contributing to this decline identified in the current assessment included, for many countries, lack of appropriate regulations, poor enforcement of existing regulations, IUU fishing, and poor or no commitment to effective management at both regional and national levels $[38,39]$. On the other hand, there are some noteworthy exceptions. Epinephelus striatus was recently included on the Specially Protected Areas and Wildlife (SPAW) protocol developed by the Convention for the Protection and Development of the Marine Environment in the Wider Caribbean Region for 2017-18, and on the endangered species list of the USA, and its protection is therefore now attracting more international and national attention.

Management that is in place for groupers is sparse and, even where measures exist, enforcement is often lax or ineffective. For about $50 \%$ of the species listed as threatened, there is still no species-specific protection other than incidentally from Marine Protected Areas (MPAs) that overlap their distributions and few groupers are regularly monitored at the species level (many are lumped into a 'grouper' category). For some species, such as the VU E. itajara, the protection of juvenile nursery areas in mangroves is important and has been achieved in some parts of its range by spatial protection; the species was also subject to a moratorium (e.g., Ref. [40]). However, most MPAs are small and designed for more sedentary species and hence insufficient for species with large home ranges, or to provide protection for migratory corridors when adults move to and from home reefs to spawn, or include the external spawning aggregation sites easily targeted by fishers at such times [41-45]. In addition, on the global level, most MPAs are placed in nearshore areas, and thus frequently exclude both offshore and deep-reef areas that are important for many groupers during part of most of their life history (UNEP-WCMC and IUCN, 2018).

Various fishing regulations are in place for some grouper fisheries, such as limits on gear type, catch quotas, size (minimum and/or maximum), and seasonal or spatial fishery closures. In many cases, however, the lack of historical and/or species-specific data on fishery catch and effort, as well as biological studies on life history characteristics, results in deficient fishery management and precludes adaptive management. Typically however, even where regulations exist, these are often undermined by poor or absent enforcement, IUU fishing, lack of government commitment, and intensifying demand and prices. In northwest Africa, for example, attempts to reduce fishing pressure on the NT $E$. aeneus, one of the most heavily exploited groupers according to data reported to the FAO [24] through the implementation of seasonal closures and MPAs have been ineffective due to a lack of enforcement and increasing demand from the small-scale fishing sector [46]. Protection from fishing pressure during spawning seasons and/or at spawning aggregation sites has been sporadically and increasingly introduced in certain parts of the world, although these (or indeed other management) measures remain infrequently applied in east and southeast Asia, where grouper diversity is highest and where landings and demand are increasing. Using examples of threatened species successful protection, which involves sufficient enforcement and/or community support, has led to increased abundance at FSAs. For the Nassau grouper, in the western Atlantic significant increases in abundance in aggregations were recorded from an aggregation in the Cayman Islands following more than a decade of consistent and effective protection [67] while in Belize aggregation numbers stabilized following protection of all those known in the country. In the Indo-Pacific, abundance of $E$. fuscoguttatus and E. polyphekadion increased in protected FSAs in Papua New Guinea [47]. In Palau, $P$. areolatus increased several fold after a decade of protection in a multi-species aggregation site (Sadovy, Colin, Bukurrou and Lindfield, unpublished data).

The vulnerability of a fish species to overfishing is closely linked to a set of life history and behavioral traits that influence susceptibility to overfishing (see bullets below) and the capacity of a population to recover once depleted $[48,49,75]$. In particular, fish species that are slow growing, long-lived, late to mature, and experience low natural mortality are consistently demonstrated to exhibit a reduced resilience and increased risk of population collapse in response to fishing [50,73, 74]. Since these traits often correlate with each other as intrinsic indicators of vulnerability [51], fishes are often ascribed specific categories that reflect their vulnerability. Within this context, many of the species of groupers within threatened categories are best described as periodic [52] or episodic strategists [53] based on their large body size, slow growth, late maturity, and long-lifespan (e.g. E. itajara, E. fuscoguttatus, E. jordani). In the absence of fishing, these species exhibit a low degree of variability in population size and size/age structure (i.e. a steady state pattern) in which annual recruitment is sporadic and can represent only a small fraction of the population biomass. Exploited $P$. leopardus also show strong inter-annual fluctuations in recruitment highlighting the importance of sporadic year classes [54]. Such species can exhibit rapid population declines when heavily fished, particularly when large individuals are targeted, and slow recovery once populations are protected. For these species, management efforts must focus on maintaining the age structure of populations and protecting old, highly fecund fishes to ensure the population survives long periods of poor environmental conditions [52].

Similar to life history traits, certain spawning behaviors are associated with productivity and resilience, in which the spatial and temporal components of spawning greatly influence how a species responds to fishing pressure [55-57]. Many of the grouper species within threatened categories reproduce within large spawning aggregations that occur at very few, specific locations during brief and predictable times of the year.

These traits are linked to reduced resilience to fishing pressure:

- Number of spawning sites positively correlated with reproductive potential [58].

- Large increases in fish density during spawning increases vulnerability to fishing $[59,60]$.

- Spawning season duration is inversely correlated to vulnerability $[61,62]$.

- Possible depensatory effects whereby aggregations allowed to drop to very low numbers, may become particularly difficult to recover [63].

Overall, there is a clear and compelling need for governments to acknowledge the multi-million dollar economic value of grouper fisheries, their economic and food benefits, and the ecosystem role of epinephelid species. To understand economic benefits, value chain analyses could determine how best to capture monetary value in source countries 
and communities (i.e. as opposed to export trade) and demonstrate the value of these fisheries at different stages of the trade chain (e.g. Refs. [64]). This could create greater incentive and much-needed political will for monitoring and management. This taxon is also one of the most threatened among reef fish species assessed according to IUCN criteria listed to date, and particular attention should be paid to managing larger, longer-lived species, and those that form spawning aggregations, if these are exploited [2].

Determination of length at maturity and minimum size limits or protected areas could help reduce the capture of juveniles, which appears to be increasing, and the greater use of hatchery-produced fish within the mariculture industry is to be encouraged to replace wild capture of juveniles (still extensively taken for grow-out). Economic evaluation of the tourism benefits in some countries would highlight the often considerable benefits of dive ecotourism for some of the larger species, as well as for spawning aggregations. Species-specific monitoring is important to detect species-specific declines. Finally, in addition to better management, for species that are particularly threatened by international trade, such as $E$. polyphekadion, $P$. areolatus, and E. aeneus and possibly others, a CITES Appendix II listing becomes an option for increasing oversight at the international level and could prompt better controls on catch and trade.

\section{Conclusions}

Groupers are among the most highly valued reef fishes and increasingly important in international trade. However 11-26\% (depending on assumptions about DD species) of the 167 species assessed are now listed as threatened with relatively few species or stocks being adequately managed and the likelihood that threats will increase on some species. Unlike many economically valued species in global fisheries, groupers attract relatively little monitoring or documentation (catches and trade volumes and values, by species) and, moreover, are typically undervalued by governments for their economic, ecosystem, and food contributions; the international live reef food fish trade is a prime example of this, being valued at over 1 billion USD at retail but largely unmanaged. In the few cases where protection was introduced specifically for threatened species, management did not start until populations were substantially reduced rather than being used proactively and in a precautionary manner. Enforcement typically remains weak and coastal reef fisheries in general, of which groupers represent an important part, are little regarded in practice by most fishery departments.

Despite the dearth of management, there are some encouraging and positive examples where protection has kick-started recovery. A moratorium on the VU E. itajara in State and Federal U.S. waters evidently brought about the start of recovery as indicated by elevated numbers of juveniles off Florida [40,65] and the recolonization of spawning aggregations in parts of northern Florida [72]. Sustained protection of localities and seasons for aggregating CR E. striatus in the Cayman Islands and Belize have helped to start significant recovery (Cayman Is.) or at least slowed declines (Belize) $[66,67]$. In the US Virgin Islands, the LC E. guttatus (Red hind) increased in abundance, catches and mean body size after protection of its spawning aggregations [68]. Protective measures are also slowly increasing in the Pacific with seasonal and spatial measures introduced to protect spawning aggregations of the VU $E$. polyphekadion, $P$. areolatus (Squaretail coralgrouper) and E. fuscoguttatus in Palau, Pohnpei, and Fiji $[63,69,71]$. Evidence of increasing abundance in parts of Australia for the NT E. daemelii (Saddletail grouper) followed the implementation of stringent fishing regulations and protection [70]. The LC Hyporthodus quernus (Hawaiian grouper) a Hawaiian Islands endemic, has nearly $75 \%$ of its range within the Papahanoumokuakea Marine National Monument and the Pacific Remote Islands National Wildlife Refuge where it is protected from fishing pressure. Elsewhere in its range, catch limits and areal closures are stringently enforced, allowing the species to maintain a stable population. In all cases, such measures were associated with research activities, strong political will, enforcement, and will likely require a decade or more to be effective.

The Red List assessment process helps to identify and draw attention to threatened species and to highlight the major threats that they face. This, in turn, reveals data gaps, enables prioritization of species or fisheries/fishing practices in need of management and monitoring and the importance of long-term monitoring at the species level to determine trends over time and space. The value of groupers in the economy can be documented using value chain analyses to identify strategic action points along the trade chain [64]. Studies on the biology and ecology of different grouper species can assist precautionary management decisions since we know that larger, longer-lived, species may be those most vulnerable to fishing and that aggregation-spawning species are particularly susceptible to overfishing. Areas that harbor high proportions of threatened or DD species call for special attention to encourage workers in the region to focus more attention on the taxon in terms of biology, fisheries and trade. Given the growth in export markets, greater resolution of the international harmonized code for monitoring trade could provide valuable insights into targeted species, areas of provenance and major demand centers. Given the expansion of aquaculture, the use of unmanaged juvenile fisheries as a source for cage/pond grow-out to market size should be phased-out.

\section{Author statement}

All authors contributed equally in conceptualization and methodology. YSJ, MTC, GAR wrote the original draft. All authors contributed to the review and editing of the final paper.

\section{Declaration of competing interest}

None.

\section{Acknowledgements}

We would like to thank other members of the Groupers and Wrasses Specialist Group, experts and invited workshop attendees: Patricia Amorim, Bruce Leung Lap Boon, Thierry Chan, Howard Choat, Ana Lidia Gaspar, Eva Giacomello, Christopher Koenig, Calton Law, Min Liu, Ka Yan Ma, Jenny MacIlwain, Simone Marques, Rob Myers, Jan Robinson, Luiz Rocha, Barry Russell, Eloy Sosa Cordero, Santi Suharti, Allen To, and Sarah Tucker. Diya Das and Rachel Wong assisted with data compilation. Universidade dos Açores provided additional support. Funding to support the workshop was provided by Ocean Park Conservation Fund - Hong Kong; Mohamed bin Zayed Species Conservation Fund; The University of Hong Kong, Governo dos Açores, and the United States Voluntary funds through IUCN.

\section{Appendix A. Supplementary data}

Supplementary data to this article can be found online at https://doi. org/10.1016/j.marpol.2020.103909.

\section{References}

[1] P.J. Jacques, Are world fisheries a global panarchy? Mar. Pol. 53 (2015) 165-170.

[2] Y. Sadovy de Mitcheson, M.T. Craig, A.A. Bertoncini, K.E. Carpenter, W.L. Cheung, J.H. Choat, A.S. Cornish, S.T. Fennessy, B.P. Ferreira, P.C. Heemstra, M. Liu, R. F. Myers, D.A. Pollard, K.L. Rhodes, L.A. Rocha, B.C. Russell, M.A. Samoilys, J. Sanciangco, Fishing groupers towards extinction: a global assessment of threats and extinction risks in a billion dollar fishery, Fish Fish. 14 (2013) 119-136.

[3] W.L. Smith, M.T. Craig, Casting the percomorph net widely: the importance of broad taxonomic sampling in the search for the placement of serranid and percid fishes, Copeia (2007) 35-55, 2007.

[4] A.C. Lautredou, H. Motomura, C. Gallut, C. Ozouf-Costaz, C. Cruaud, G. Lecointre, A. Dettai, New nuclear markers and exploration of the relationships among Serraniformes (Acanthomorpha, Teleostei): the importance of working at multiple scales, Mol. Phylogenet. Evol. 67 (2013) 140-155. 
[5] W.L. Smith, E. Everman, C. Richardson, Phylogeny and taxonomy of flatheads, scorpionfishes, sea robins, and stonefishes (Percomorpha: scorpaeniformes) and the evolution of the lachrymal saber, Copeia 106 (2018) 94-119.

[6] G.D. Johnson, Niphon spinosus: a primitive epinepheline serranid, with comments on the monophyly and intrarelationships of the Serranidae, Copeia (1983) 777-787, 1983.

[7] G.D. Johnson, Niphon spinosus, a primitive epinepheline serranid: corroborative evidence from the larvae, Jpn. J. Ichthyol. 35 (1988) 7-18.

[8] R.R. Betancur, E.W. Wiley, G. Arratia, A. Acero, N. Bailly, M. Miya, G. Lecointre, G. Ortí, Phylogenetic classification of bony fishes, BMC Evol. Biol. 17 (2017) 1-40.

[9] K.Y. Ma, M.T. Craig, An inconvenient monophyly: an update on the taxonomy of the groupers (Epinephelidae), Copeia 106 (2018) 443-456.

[10] M.T. Craig, P.A. Hastings, A molecular phylogeny of the groupers of the subfamily Epinephelinae (Serranidae) with a revised classification of the Epinephelini, Ichthyol. Res. 54 (2007) 1-17.

[11] G.M. Mace, N.J. Collar, K.J. Gaston, C. Hilton-Taylor, H.R. Akçakaya, N. LeaderWilliams, E.J. Milner-Gulland, S.N. Stuart, Quantification of extinction risk: IUCN's system for classifying threatened species, Con. Biol. 22 (2008) 1424-1442.

[12] M. Depczynski, D.R. Bellwood, Extremes, plasticity, and invariance in vertebrate life history traits: insights from coral reef fishes, Ecology 87 (2006) 3119-3127.

[13] IUCN, IUCN Red List Categories and Criteria, Version 3.1, second ed., 2016 (Gland, Switzerland and Cambridge, UK).

[14] IUCN, Guidelines for appropriate uses of IUCN red list data, in: Incorporating, as Annexes, the 1) Guidelines for Reporting on Proportion Threatened (Ver. 1.1); 2) Guidelines on Scientific Collecting of Threatened Species (Ver. 1.0); and 3), 2016 Guidelines for the Appropriate Use of IUCN Red List by Business (ver. 1.0). Version 3. Adopted by the IUCN Red List Committee.

[15] IUCN Standards and Petitions Subcommittee, Guidelines for Using the IUCN Red List Categories and Criteria, Version 13. Prepared by the Standards and Petitions Subcommittee, 2017. Retrieved from, https://cmsdocs.s3.amazonaws.com/RedLis tGuidelines.pdf.

[16] J.C. Rice, È. Legacè, When control rules collide: a comparison of fisheries management reference points and IUCN criteria for assessing risk of extinction, ICES (Int. Counc. Explor. Sea) J. Mar. Sci. 64 (2007) 718-722.

[17] T.D. Davies, J.K. Baum, Perspectives on the status of marine fishes, Sci. Rep. 2 (2012) 561.

[18] P.G. Fernandes, G.M. Ralph, A. Nieto, M.G. Criado, P. Vasilakopoulos, C D. Maravelias, R.M. Cook, R.A. Pollom, M. Kovačić, D. Pollard, E.D. Farrell, A. B. Florin, B.A. Polidoro, J.M. Lawson, P. Lorance, F. Uiblein, M. Craig, D.J. Allen, S. L. Fowler, R.H.L. Walls, M.T. Comeros-Raynal, M.S. Harvey, M. Dureuil, M. Biscoito, C. Pollock, S.R. McCully Phillips, J.R. Ellis, C. Papaconstantinou, A. Soldo, Ç. Keskin, S.W. Knudsen, L.G. de Sola, F. Serena, B.B. Collette, K. Nedreaas, E. Stump, B.C. Russell, S. Garcia, P. Afonso, A.B.J. Jung, H. Alvarez, J. Delgado, N.K. Dulvy, K.E. Carpenter, Coherent assessments of Europe's marine fishes show regional divergence and megafauna loss, Nature Ecol. and Evol. 1 (2017), 0170

[19] IUCN Standards and Petitions Committee, Guidelines for Using the IUCN Red List Categories and Criteria. Version 14. Prepared by the Standards and Petitions Committee, 2019 (Downloadable from http).

[20] Capture-based aquaculture, in: A. Lovatelli, P.F. Holthus (Eds.), Global Overview, 2009.

[21] A.W.L. To, Y. Sadovy de Mitcheson, Shrinking baseline: the growth in juvenile fisheries, with the Hong Kong grouper fishery as a case study, Fish Fish. 10 (2009) 396-407.

[22] R. Nair, Epinephelus diacanthus. The IUCN Red List of Threatened Species 2018: e. T132777A46629928, 2018, https://doi.org/10.2305/IUCN.UK.2018-2. RLTS. T132777A46629928.en.

[23] Y. Sadovy de Mitcheson, I. Tam, G. Muldoon, S. le Clue, E. Botsford, S. Shea, The Trade in Live Reef Food Fish - Going, Going, Gone, Main Report. Parts I, II \& III vol. 1, ADM Capital Foundation and The University of Hong Kong, 2017, pp. 1-288. Hong Kong Special Administrative Region, https://www.admcf.org/re search-reports/live-trade-live-reef-food-fish-going-going-gone-volume-1/.

[24] FAO, Fisheries Technical Paper, No. 508, FAO, Rome, 2008, p. 298.

[25] D. Pauly, D. Zeller, Catch reconstructions reveal that global marine fisheries catches are higher than reported and declining, Nat. Commun. 7 (2016) 10244.

[26] FAO, Workshop on improving our knowledge on small-scale fisheries: data needs and methodologies, in: Workshop Proceedings, 27-29 June 2017, Rome, Italy, FAO Fisheries and Aquaculture Proceedings No. 55, Rome, Italy, 2017.

[27] H. Kindsvater, J. Reynolds, Y. Sadovy de Mitcheson, M. Mangel, Selectivity matters: rules of thumb for management of plate-sized, sex-changing fish in the live reef food fish trade, Fish Fish. 18 (2017) 821-836.

[28] B. Polidoro, G. Ralph, K. Strongin, M. Harvey, K. Carpenter, T. Ayo Adeofe, R. Arnold, P. Bannerman, J.N. Bibang Bi Nguema, J. Buchanan, K.M.A. Camara, Y. H. Camara, K. Cissoko, B.B. Collette, M.T. Comeros-Raynal, G. De Bruyne, M. Diouf, R. Djiman, M. Ducrocq, O. Gon, A.S. Harold, H. Harwell, C. HiltonTaylor, A. Hines, P.A. Hulley, T. Iwamoto, S. Knudsen, J. De Dieu Lewembe, C. Linardich, K. Lindeman, E.M. Mbye, J.E. Mikolo, J. Monteiro, J.B. Mougoussi, T. Munroe, J.H. Mve Beh, F.K.E. Nunoo, C. Pollock, S. Poss, R. Quartey, B. Russell, A. Sagna, C. Sayer, A. Sidibe, W. Smith-Vaniz, E. Stump, M. Sylla, L.T. De Morais, J. C. Vié, A. Williams, Red List of Marine Bony Fishes of the Eastern Central Atlantic, IUCN, Gland, Switzerland, 2016, p. 80, viii +.

[29] O. Aburto-Oropeza, B. Erisman, V. Valdez-Ornelas, G. Danemann, Commercially important serranid fishes from the Gulf of California: ecology, fisheries, and conservation, Cienc. y Cons. 1 (2008) 1-44.

[30] P. Usseglio, A.M. Friedlander, E.E. DeMartini, A. Schuhbauer, E. Schemmel, P. Salinas de Léon, Improved estimates of age, growth and reproduction for the regionally endemic Galapagos sailfin grouper Mycteroperca olfax (Jenyns, 1840), PeerJ e270 (2015) 1-20.

[31] P. Usseglio, A.M. Friedlander, H. Koike, J. Zimmerhackel, A. Schuhbauer, T. Eddy, P. Salinas-de- Léon, So long and thanks for all the fish: overexploitation of the regionally endemic Galapagos grouper, PloS One 11 (2016), e0165167.

[32] R.G. Asch, B. Erisman, Spawning aggregations act as a bottleneck influencing climate change impacts on a critically endangered reef fish, Divers. Distrib. 24 (2018) 1712-1728.

[33] S.W. Dunlop, B.Q. Mann, An assessment of the offshore boat-based linefishery in KwaZulu-Natal, South Africa, Afr. J. Mar. Sci. 351 (2013) 79-97.

[34] P.J. Mous, J.S. Pet, Length-based assessment of data-poor multi-species deep grouper fisheries in fisheries management areas (WPP) 573, 712, 713, 714, 715 \& 718 in Indonesia, TNC-IFCP Technical Paper, in: The Nature Conservancy/People and Nature Consulting International vol. 79, 2016.

[35] D.R. Bellwood, T.P. Hughes, C. Folke, M. Nystrom, Confronting the coral reef crisis, Nature 429 (2004) 827-833.

[36] E. Sala, E. Ballesteros, R.M. Starr, Rapid decline of Nassau grouper spawning aggregations in Belize: fishery management and conservation needs, Fisheries 26 (2001) 23-30.

[37] G. Shideler, B. Pierce, Recreational diver willingness to pay for goliath grouper encounters during the months of their spawning aggregation off eastern Florida, USA, Ocean Coast Manag. 129 (2016) 36-43.

[38] A. Aguilar-Perera, C. Gonzalez-Salas, H. Villegas-Hernandez, Fishing, management and conservation of the Nassau grouper, Epinephelus striatus, in the Mexican caribbean, Proc. Gulf Caribb. Fish. Inst. 61 (2009) 313-319.

[39] K.D. Sherman, A.D. Shultz, C.P. Dahlgren, C. Thomas, E. Brooks, A. Brooks, D. R. Brumbaugh, K.J. Murchie, Contemporary and emerging fisheries in the Bahamas - conservation and management challenges, achievements and future directions, Fish. Manag. Ecol. 25 (2018) 319-331.

[40] C.C. Koenig, F.C. Coleman, A.M. Eklund, J. Schull, J. Ueland, Mangrove as essential nursery habitat for goliath grouper (Epinephelus itajara), Bull. Mar. Sci. 80 (2007) $567-586$.

[41] S.K. Bolden, Long-distance movement of a Nassau grouper (Epinephelus striatus) to a spawning aggregation in the central Bahamas, Fish. Bull. 98 (2000) 642-645.

[42] J.C. McGovern, D.M. Wyanski, O. Pashuk, C.S. Manooch II, G.R. Sedberry, Changes in the sex ratio and size at maturity of Gag, Mycteroperca microlepis, from the Atlantic coast of the southeastern United States during 1976-1995, Fish. Bull. 96 (1998) 797-807.

[43] R.S. Nemeth, J. Blondeau, K.E. Herzlieb, Spatial and temporal patterns of movement and migration at spawning aggregations of red hind, Epinephelu. guttatus, in the U.S. Virgin Islands, Environ. Biol. Fish. 78 (2007) 365-381.

[44] K.L. Rhodes, M.H. Tupper, The vulnerability of reproductively active squaretail coralgrouper (Plectropomus areolatus) to fishing, Fish. Bull. 106 (2008) 194-203.

[45] R. Ellis, C.C. Koenig, F.C. Coleman, Spawning-related movement patterns of goliath grouper (Epinephelus itajara) off the Atlantic Coast of Florida, Proc. Gulf Caribb. Fish. Inst. 66 (2014) 395-400.

[46] D. Thiao, C. Chaboud, A. Samba, F. Laloë, P.M. Cury, Economic dimension of the collapse of the 'false cod' Epinephelus aeneus in a context of ineffective management of the small-scale fisheries in Senegal, Afr. J. Mar. Sci. 34 (2012) 305-311.

[47] R.J. Hamilton, T. Potuku, J. Montambault, Community-based conservation results in the recovery of reef fish spawning aggregations in the Coral Triangle, Biol Conserv. 144 (2011) 1850-1858.

[48] P.B. Adams, Life history patterns in marine fishes and their consequences for fisheries management, Fish. Bull. 78 (1980) 1-12.

[49] I. Stobutzki, M. Miller, D. Brewer, Sustainability of fishery bycatch: a process for assessing highly diverse and numerous bycatch, Environ. Conserv. 28 (2001) 167-181, https://doi.org/10.1017/S0376892901000170.

[50] S. Jennings, J.D. Reynolds, S.C. Mills, Life history correlates of responses to fisheries exploitation, Proc. Roy. Soc. B-Biol. Sci. 265 (1998) 333-339, https://doi. org/10.1098/rspb.1998.0300.

[51] N.K. Dulvy, J.R. Ellis, N.B. Goodwin, A. Grant, J.D. Reynolds, S. Jennings, Methods of assessing extinction risk in marine fishes, Fish Fish. 5 (2004) 255-276, https:// doi.org/10.1111/j.1467-2679.2004.00158.x.

[52] J.R. King, G. McFarlane, Marine fish life history strategies: applications to fishery management, Fish. Manag. Ecol. 10 (2003) 249-264, https://doi.org/10.1046/ j.1365-2400.2003.00359.x.

[53] H.K. Kindsvater, M. Mangel, J.D. Reynolds, N.K. Dulvy, Ten principles from evolutionary ecology essential for effective marine conservation, Ecol. Evol. 6 (2016) 2125-2138, https://doi.org/10.1002/ece3.2012.

[54] B.P. Ferreira, G.R. Russ, Population structure of the leopard coralgrouper, Plectropomus leopardus, on fished and unfished reefs off Townsville, Central Great Barrier Reef, Aust. Fish. Bull. 93 (1995) 629-642.

[55] J. Robinson, N.A.J. Graham, J.E. Cinner, G.R. Almany, P. Waldie, Fish and Fisher behaviour influence the vulnerability of groupers (Epinephelidae) to fishing at a multispecies spawning aggregation site, Coral Reefs 34 (2015) 371-382, https:// doi.org/10.1007/s00338-014-1243-1.

[56] B. Erisman, W. Heyman, S. Kobara, T. Ezer, S. Pittman, O. Aburto-Oropeza, R. S. Nemeth, Fish spawning aggregations: where well-placed management actions can yield big benefits for fisheries and conservation, Fish Fish. 181 (2017) 128-144, https://doi.org/10.1111/faf.12132.

[57] S. Lowerre-Barbieri, G. DeCelles, P. Pepin, I.A. Catalán, B. Muhling, B. Erisman, S. X. Cadrin, J. Alós, A. Ospina-Alvarez, M.M. Stachura, M.D. Tringali, S.W. Burnsed, C.B. Paris, Reproductive resilience: a paradigm shift in understanding spawnerrecruit systems in exploited marine fish, Fish Fish. 18 (2017) 285-312.

[58] S. Lowerre-Barbieri, L. Crabtree, T. Switzer, S.W. Burnsed, C. Guenther, Assessing reproductive resilience: an example with South Atlantic red snapper Lutjanus 
campechanus, Mar. Ecol. Prog. Ser. 526 (2015) 125-141, https://doi.org/10.3354/ meps11212.

[59] B. Erisman, L.G. Allen, J.T. Claisse, D.J. Pondella II, E.F. Miller, J.H. Murray, The illusion of plenty: hyperstability masks collapses in two recreational fisheries that target fish spawning aggregations, Can. J. Fish. Aquat. Sci. 68 (2011) 1705-1716, https://doi.org/10.1139/F2011-090.

[60] M.J. Wilberg, J.T. Thorson, B.C. Linton, J. Berkson, Incorporating time-varying catchability into population dynamic stock assessment models, Rev. Fish. Sci. 18 (2010) 7-24, https://doi.org/10.1080/10641260903294647.

[61] R. Claro, Y. Sadovy de Mitcheson, K.C. Lindeman, A.R. García-Cagide, Historical analysis of Cuban commercial fishing effort and the effects of management interventions on important reef fishes from 1960-2005, Fish. Res. 991 (2009) 7-16, https://doi.org/10.1016/j.fishres.2009.04.004.

[62] Y. Sadovy De Mitcheson, B.E. Erisman, Fishery and biological implications of fishing spawning aggregations, and the social and economic importance of aggregating fishes, in: Y. Sadovy De Mitcheson, P.L. Colin (Eds.), Reef Fish Spawning Aggregations: Biology, Research and Management, Springer, 2012, https://doi.org/10.1007/978-94-007-1980-4.

[63] Y. Sadovy de Mitcheson, Mainstreaming fish spawning aggregations into fishery management calls for truly precautionary approach, Bioscience 66 (2016) 295-306.

[64] Y. Sadovy de Mitcheson, S. Mangubhai, A. Witter, N. Kuridrani, A. Batibasaga, P. Waqainabete, R. Sumaila, Value chain analysis of the Fiji grouper fishery, in: Report of Science and Conservation of Fish Aggregations (SCRFA) Https://Www. researchgate.net/Publication/328772613_Value_Chain_Analysis_of_the_Fiji_ Grouper Fishery, SCRFA, 2018, p. 57. United States.

[65] C.C. Koenig, F. Coleman, K. Kingon, Pattern of recovery of the goliath grouper Epinephelus itajara population in the southeastern US, Bull. Mar. Sci. 874 (2011) 891-911.

[66] V. Burns Perez, A. Tewfik, Brief history of management and conservation of Nassau grouper and their spawning aggregations in Belize: a Collaborative Approach, Proc. Gulf Caribb. Fish. Inst. 69 (2016) 1-10.
[67] L. Waterhouse, S.A. Heppell, C.V. Pattengill-Semmens, C. McCoy, P. Bush, B. C. Johnson, B.X. Semmens, In 2020. Recovery of critically endangered Nassau grouper (Epinephelus striatus) in the Cayman Islands following targeted conservation actions, Proc. Natl. Acad. Sci. Unit. States Am. (2020).

[68] R.S. Nemeth, Population characteristics of a recovering US Virgin Islands red hind spawning aggregation following protection, Mar. Ecol. Prog. Ser. 286 (2005) $81-97$.

[69] K.L. Rhodes, B.M. Taylor, J.L. McIlwain, Detailed demographic analysis of an Epinephelus polyphekadion spawning aggregation and fishery, Mar. Ecol. Prog. Ser. 421 (2011) 183-198.

[70] M.P. Francis, D. Harasti, H.A. Malcolm, Surviving under pressure and protection: a review of the biology, ecology and population status and of the highly vulnerable grouper, Epinephelus daemelii. Mar. Freshw. Res. 67 (2015) 1215-1228.

[71] The Fiji Times, 2018. https://www.fijitimes.com/grouper-fish-research/.

[72] C. Malinowski, F. Coleman, C. Koenig, J. Locascio, D. Murie, Are Atlantic goliath grouper, Epinephelus itajara, establishing more northerly spawning sites? Evidence from the northeast Gulf of Mexico, Bull. Marine Sci. (2019), https://doi.org/ 10.5343/bms.2018.0062.

[73] Kirk Winemiller, Life history strategies, population regulation, and implications for fisheries management, Can. J. Fish. Aqua. Sci. 62 (2005), https://doi.org/10.1139/ f05-040.

[74] J.A. Musick, et al., Marine, estuarine, and diadromous fish stocks at risk of extinction in north America (Exclusive of Pacific Salmonids), Fisheries 25 (11) (2000) 6-30.

[75] John Reynolds, Simon Jennings, Nicholas Dulvy, Life histories of fishes and population responses, Conserv. Exploit. Spec. (2001) 147-168.

[76] B.B. Collette, K.E. Carpenter, B.A. Polidoro, M.J. Juan-Jordá, A. Boustany, D.J. Die, C. Elfes, W. Fox, J. Graves, L.R. Harrison, R. McManus, C.V. Minte-Vera, R. Nelson, V. Restrepo, J. Schratwieser, C.-L. Sun, A. Amorim, M. Brick Peres, C. Canales, G. Cardenas, S.-K. Chang, W.-C. Chiang, N. de Oliveira Leite Jr., H. Harwell, R. Lessa, F.L. Fredou, H.A. Oxenford, R. Serra, K.-T. Shao, R. Sumaila, S.-P. Wang, R. Watson, E. Yáñez, High Value and Long Life-Double Jeopardy for Tunas and Billfi shes, Science 333 (15 July 2011) 291-292. www.sciencemag.org. 